\title{
Evaluation of the Smallholder Farmers' Perception and Acceptance for Push-Pull Technology in Western Hararghe Zone of Oromia, Ethiopia
}

\author{
Abebe Teshome*, Belay Roba \\ Ethiopian Institute of Agricultural Research, Department of Agricultural Economics, Finfine, Ethiopia \\ Email address: \\ Abebegurmu3@gmail.com (A. Teshome), robabelay143@gmail.com (B. Roba) \\ ${ }^{*}$ Corresponding author \\ To cite this article: \\ Abebe Teshome, Belay Roba. Evaluation of the Smallholder Farmers' Perception and Acceptance for Push-Pull Technology in Western \\ Hararghe Zone of Oromia, Ethiopia. American Journal of Agriculture and Forestry. Vol. 8, No. 3, 2020, pp. 81-90. \\ doi: 10.11648/j.ajaf.20200803.15
}

Received: August 12, 2019; Accepted: September 6, 2019; Published: June 17, 2020

\begin{abstract}
Cereal crops play an important role in ensuring food security in Africa and providing cash income for most households in the rural areas. In the last two decades, African region has been experiencing a significant decline in per capita food production in which the cereals explaining most of the observed variance in total food production. The decline in cereal production causes food self insufficiency and exposes the smallholder farmers and rural communities as whole to food shortage and famines. Striga weed and stem borers were among the major pests that contribute to the significant decline in cereals production in Ethiopia. In response to these challenges the Agricultural research Institutes both at national and international level has come up with various control strategies. Among these, Push-Pull technology was one of the strategies to cope the significant decline in cereals production. The Technology has been one of the most successful methods and with an advantage of controlling both the stem borers and striga weed simultaneously, while improving soil fertility status. The technology provides an integrated soil and pest management that makes an efficient use of natural resource to increase farm productivity. Even though the result from on farm research experiments and pre-extension demonstration revealed the positive effect of the push pull technology in improving production and productivity of cereal crops in different parts of Ethiopia (Boset, Mieso, Habro and Daro Labu), perception and acceptance of the wider smallholder farmers for the technology was not evaluated. Hence, this study was intended to analyze perception and acceptance of the smallholder farmers for the push pull technology in Habro and Daro Labu districts of western hararghe zone of Oromia regional state, Ethiopia. Ten kebeles and 81 farmers implementing the push-pull technology were purposively selected and interviewed using structured questionnaire. Both primary and secondary data used to attain the research objectives. The structured questionnaire was a primary data collection tool. Collected primary data analyzed using the Statistical Package of Social Science software (SPSS). From the total sample farm households, about $77.8 \%$ of them were fully agree and $9 \%$ of them were agree with the idea that push-pull technology is efficient in controlling stem borer and improve the production and productivity of the cereals (maize and sorghum) in the study area. Smallholder farmers perceive benefits of the push pull technology through its role in improving the cereal yield by improving soil fertility, maintaining soil moisture, reducing soil erosion and the negative effect of striga.
\end{abstract}

Keywords: Push-pull, Farmers Research Group, Smallholder Farmers

\section{Background and Justification}

Cereal crops are crucially important to food security in Africa, providing the daily calories and cash income for most households in the rural areas. In the last two decades, African region has been experiencing a decline in the per capita food production, with cereal explaining most of the observed variance in total food production [3]. This instability in cereal production has continuously affected food self sufficiency in the region thus exposing the communities to food shortages 
and famines. Many constraints have been ascribed to the acute food shortages with the stem borers, striga weed and land degradation notably taking the lead [9]. Although farmers have made attempts to contain the negative effects of the two pests, the control measures they have taken have been futile. Thus, the productivity of cereal crops in Africa has continued to dwindle subjecting most rural households to abject poverty.

Responding to some of these challenges, research organization both national and international has come up with various control strategies to manage these constraints. Among them is push-pull technology which was developed and promoted by the International Centre of Insect Physiology and Ecology (icipe). The conventional push-pull technology utilizes plant to plant interaction to repel the stem borer moths as well as to put the striga weed under control [10]. The technology has been one of the most successful methods and with an advantage of controlling both the stem borers and striga weed simultaneously, while improving soil fertility status. Push-pull, an innovative conservation agriculture technology provides an integrated soil and pest management that make efficient use of natural resources to increase farm productivity [6]. The technology effectively controls the major insect pests of cereals in Sub Saharan Africa, the lepidopteron stem borers, and the devastating parasitic striga weeds, both of which can cause total yield loss. Furthermore it improves soil health and conserves soil moisture.

The push-pull technology is an ecological approach for effective pest and weed management based on a combined use of inter and trap cropping systems where stem borers are driven away from maize by push plants and attracted by and trapped on the trap plants and where the parasitic striga weeds are effectively controlled through root exudates from the Desmodium plants [13].

Push-pull technology involves use of intercrops and trap crops in a mixed cropping system. These companion plants release behavior-modifying stimuli (chemical) to manipulate the distribution and abundance of stem borers and beneficial insects for management of stem borer pests.

The system relies on an in-depth understanding of chemical ecology, agro biodiversity, and plant-plant and insect-plant interactions and is well suited to African socioeconomic conditions.

The main cereal crop is planted with a repellent intercrop such as Desmodium (push) and attractive trap plant such as Napier grass (pull) planted as a border crop around this intercrop. Gravid stem borer females are repelled from the main crop and are simultaneously attracted to the trap crop [2]. As a result this female stem borer laid an egg on the trap crop (Napier grass). However, most of the stem borer larvae, about $80 \%$ do not survive, as Napier grass tissues produces sticky sap in response to feeding by the larvae which traps them and causing their mortality. Desmodium also used to controls striga weed, increase the soil fertility and contributes for a significant yield increase (Khan et al. 2008). In extensive Research and Development (R\&D) efforts, it was found that not only were stem borers and striga effectively controlled by the technology under farmers' conditions, but farmers also reported additional benefits such as increased soil fertility, up to three-fold increases in grain yields and improved availability of animal fodder resulting in increased milk production [11].

Stem-borer and striga are two high impact crop pest and weed respectively in Ethiopia which contributes to reduction in sorghum and maize production. The yield loss due to striga weed ranges between 30 and 100 percent in most areas of Ethiopia [4]. Stem-borer can cause average yield losses of 20$50 \%$ and, in some cases, a complete loss of maize and sorghum crops in Ethiopia [5]. According to Calatayud [1], B. fusca is one of the most economically important species of stem-borers which occurs in all agro-ecological zones from the lowland semi-arid and arid savannahs to the highland wet mountain forests in Africa. Hence, different cultural methods like Maize-Bean intercropping, crop residue disposal and host plant resistance have been recommended for the control of stem borers. According to Oben [15] different cultutural methods like use of wood ash and botanicals were also used for the control of stem borers in cameroon. However, these control methods are not longer convincing solution for the problem which is due to the reason that the methods are either not effective or not affordable by the smallholder farmers. Hence, the push-pull technology as the alternative stem-borer control strategy developed by International Center of Insect Physiology and ecology (ICIPE) to address the effect of stemborer on smallholder farmers' production effectively [12].

The push-pull technology was introduced in different areas of Oromia regional state (Boset, Mieso, Habro and Daro Labu) on smallholder farmers' field as a demonstration plots targeting the effectiveness of the technology in controlling stem borer.

The demonstration farmers in the area have exercised and shared knowledge on the implementation and importance of the technology. The farmers could have different insight on the practical implementation of the technology and its attributes since it is new to the farmers in the area. In this research, therefore, perception of smallholder farmers on push-pull technology assessed and examined to evaluated the level of understanding of host (demonstration farmers) and non host (non demonstration farmers) in the area depending on the observation and frequent follow up of their demonstration field against the conventional farming practices.

\section{Methodology}

\subsection{Description of the Technology}

Repellent intercrop: Desmodium (push)

Attractive trap plant: Bracharia, Napier grass or elephant Grass (Pull)

Crop: Cereal crops (sorghum and Maize)

\subsection{Description of Study Area and Sampling Techniques}

The study was conducted in Western Hararghe zone of 
Ethiopia, particularly in Habro and Daro Labu districts. The zone and two of its districts were selected purposively since, there were push-pull technology implementing farmers there. Ten kebeles and 81 farmers implementing the push-pull technology were purposively selected and interviewed using structured questionnaire.

\subsection{Data Sources, Data Collection and Data Analysis}

The farm household was the primary data source for this study. Research directories, web sites, Proceedings and journals were the other important secondary data sources used for this study. The structured questionnaire was the primary data collection tool.

\section{Results and Discussion}

\subsection{Socio Economic Description of the Farm Households}

From a total of 81 sample farm house holds 71 are male and the rest of 10 are Female headed households. The minimum family size in 81 farm households is 1 and the maximum family size is 12 . Generally, the average family size of the farmhouse hold is 7 with the standard deviation of 2.664 .

The average age of the farm households is 36 with the standard deviation of 9.27 . There are 4 children on average in each farm household whose age is below 14 years old with standard deviation of 1.98 and there are 3 individuals in each farm house hold on average whose age is 15 to 64 years.

There is a maximum of 1 person whose age is above 64 years old in each sample house hold. The maximum dependency ratio is 3.50 . The mean dependency ratio of the sample farm household is 1.49 with standard deviation of 0.96 .

The total farm size of the farm household is 0.68 hectare on average of which 0.125 hectare is minimum farm size and 1.5 hectare is maximum farm size with the standard deviation of 0.296 .

\subsection{Crop Production and Land Allocation}

There are number of crops produced in the study areas. Sorghum, Maize, teff, Chat, Common Bean and cow pea are produced in the area. Sweet potato and chick pea are also produced in the study area even if it's not widely produced as other crops. However, Sorghum and Maize is produced widely in the area. Both sorghum and maize is produced in intercropping with the push pull technology to reduce the stem borer and striga infestation which resulting a significant yield reduction in the area.

The farmers are producing both local and improved sorghum and maize varieties. About 0.03 and 0.04 hectares of land are allocated for improved sorghum and Maize Varieties on average respectively in 2014/15 Growing season. On the other hand, 0.415 and 0.056 hectares of land are allocated for local sorghum and Maize varieties on average respectively in 2014/15 growing season.

\subsection{Participation in Push-pull Technology}

From total of 81 sample farmhouseholds, 73 of them were implement the push-pull technology together with sorghum and 4 of them were implement the technology with maize. The other 4 farmers were implementing the technology together with both sorghum and maize. As indicated above most of the farmers were implementing the technology with sorghum as sorghum is widely produced in the area when compared with maize.

Area of land the farmers allocated for push technology with sorghum is increased currently when compared with the area the farmers allocated during their first involvement in the implementation of the technology. This implies that the farmers accepting the benefits of the technology and they increase the area coverage to minimize the risk due to stem borer and striga.

The area of land in kert the farmers allocated for sorghum with push pull technology currently and during their first involvement in the implementation of the technology is discussed below in detail.

Table 1. The average area of land allocated for sorghum in kert with push-pull technology.

\begin{tabular}{|c|c|c|c|c|}
\hline \multirow{2}{*}{$\begin{array}{l}\text { Year of involvement in push-pull } \\
\text { technology implementation with } \\
\text { sorghum }\end{array}$} & \multicolumn{2}{|c|}{$\begin{array}{l}\text { The Average area of land (in kert) allocated during } \\
\text { the involvement }\end{array}$} & \multicolumn{2}{|c|}{$\begin{array}{l}\text { The Average area of land (in kert) allocated } 2014 \\
\text { growing season }\end{array}$} \\
\hline & Frequency & Average land allocated in (kert) & Frequency & Average land allocated in (kert) \\
\hline 2012 & 1 & 1.6 & 1 & 1.6 \\
\hline 2013 & 28 & 0.8 & 18 & 1.6 \\
\hline 20014 & 48 & 2.4 & 48 & 2.4 \\
\hline Total & $\mathrm{N}=77$ & & $\mathrm{~N}=67$ & \\
\hline
\end{tabular}

According to the result indicated in table 1, the average area of land the farmers allocated for push technology implementation with sorghum is increased. Those farmers involved in push-pull technology implementation with sorghum in 2013 were allocated 0.8 kert on average during their involvement (in 2013) and $1.6 \mathrm{kert}$ in 2014 growing season for sorghum production with push-pull technology.

However those farmers involved in push pull technology implementation with sorghum in 2014 were allocated 2.4 kert on average for sorghum production with push-pull technology. This implies that those farmers started the implementation of push-pull technology for sorghum recently (2014) were allocated more land when compared with those farmers started to use the technology before (2012 and 2013). this is due to good information exchange about the push-pull technology between the FRG Members and Non FRG individual farmers. This means than Non FRG individual 
farmers were got good information about the technology from the previously established FRG members and started to involve in implementation of the technology for sorghum by establishing a new FRG with a good understanding and information about the technology. The role of FRG as an adoption pathway tool for the push pull technology will discussed well later.

From those farmers involved in push-pull technology implementation for sorghum in 2013 about 10 of them were discontinued to use the technology for sorghum. Even though they were interested for the technology they were forced to stop using it due to the shortage of Bracharia and Desmodium seed (Push-pull), land shortage and drought problem. Thus from total of 77 sample farm households started to use the push pull technology for sorghum including those started in 2014 only 67 of them are implementing the technology for sorghum currently.

On the other hand all of the sample farm households implementing push pull technology for maize were started to use the technology recently. Generally from the above result we conclude that, mass of the sample farm households are implement the push pull technology for sorghum than maize as they produce sorghum widely than other crops. The average area of land allocated for sorghum production with push-pull technology was also increased from 2013 to 2014 as the farmers are understand the benefits of the technology well. However, the shortage of the technology (Desmodium and Bracharia seed) is one of the factors that makes the farmers to stop using the technology and unable to use the technology for their entire sorghum farm.

\subsection{Sorghum and Maize Production Under Push-pull and Sole Cropping}

Both sorghum and maize are grown in the study area. However, sorghum is widely produced than maize and most of the sample farm households are used the push-pull technology for Sorghum than maize.

From total of 81 sample farm house holds, about, $90.1 \%$ of them were implement push pull technology for sorghum production.

Only 4.9\% were implement push pull technology for maize and the other $4.9 \%$ were implement the technology for both sorghum and maize.

Most of the sample farm households were responds as most of their sorghum production is under sole cropping since there is a shortage of push-pull technology (Desmodium and Bracharia seed). Even though there is a shortage of technology, they increased their land allocation for sorghum production with push pull technology currently when compared with area they allocate during their first time of involvement in technology implementation. Although most of their sorghum and maize production is under sole cropping and the productivity is higher under production with push-pull. Yield of sorghum and maize per hectare under sole cropping and push-pull are discussed below.

Table 2. Yield of sorghum and maize per hectare under sole cropping and push-pull.

\begin{tabular}{llllll}
\hline Type of the crop & $\mathbf{N}$ & $\begin{array}{l}\text { Mean yield/ha under sole } \\
\text { cropping }\end{array}$ & standard deviation & N & $\begin{array}{l}\text { Mean yield/ha under push-pull } \\
\text { intercropping }\end{array}$ \\
\hline Sorghum & 57 & 19.00 & 8.88 & 64 & 23.00 \\
Maize & 15 & 17.00 & 8.34 & 8 & 18.00 \\
\hline
\end{tabular}

As indicated in table 2, From 67 farmers implementing the push-pull technology with sorghum in 2014 growing season 3 of them did not get any yield due to absolute damage of their crop by drought.

But, the rest 64 farmers were successful and got good yield by producing sorghum under push-pull technology. Farmers get better sorghum yield under push-pull technology application than sole cropping. They produce 23 quintal of sorghum per hectare on average under use of push pull technology. However, they produce 19 quintal of sorghum per hectare on average under sole cropping.

Even though there is no much difference between yield of maize under push pull and under sole cropping condition, Maize yield is better under push pull technology than sole cropping. This implies that production of sorghum and Maize under push-pull technology application is better than sole cropping to get better yield by reducing yield reduction problem due to striga weeds and stem borer infestation.

The result agrees with [7] whose finding indicates that push-pull technology improves the smallholder farmers' yield in terms increased production and decreased labor demand.
This research finding also concurs with [17] who reported that Maize grain yields were significantly higher in the climate -adapted push-pull plots than in the maize mono crop plots in which maize yields ranged from 3359 to $3983 \mathrm{~kg} / \mathrm{ha}$ in the climate -adapted push-pull plots and from 2641 to $2960 \mathrm{~kg} / \mathrm{ha}$ in the maize mono crop plots.

Farmers are also benefited from the harvest of push pull (Desmodium and Bracharia). Biomass of Bracharia and Desmodium harvested are used for their livestock forage. They are very interested in Bracharia for their livestock feed. However some of the farmers are not harvest Bracharia at the right time. This in turn reduces the efficiency of the push pull technology to reduce the stem borer infestation.

Most of the time research recommends that Bracharia should be harvested when its growth (length) is $1.5 \mathrm{~m}$ and above. On the other hand most of the farmers are using this research recommendation regarding the harvesting time of Bracharia and successfully implements the technology. The average Biomass of Desmodium and Bracharia harvested in $\mathrm{Kg}$ per hectare is discussed below. 


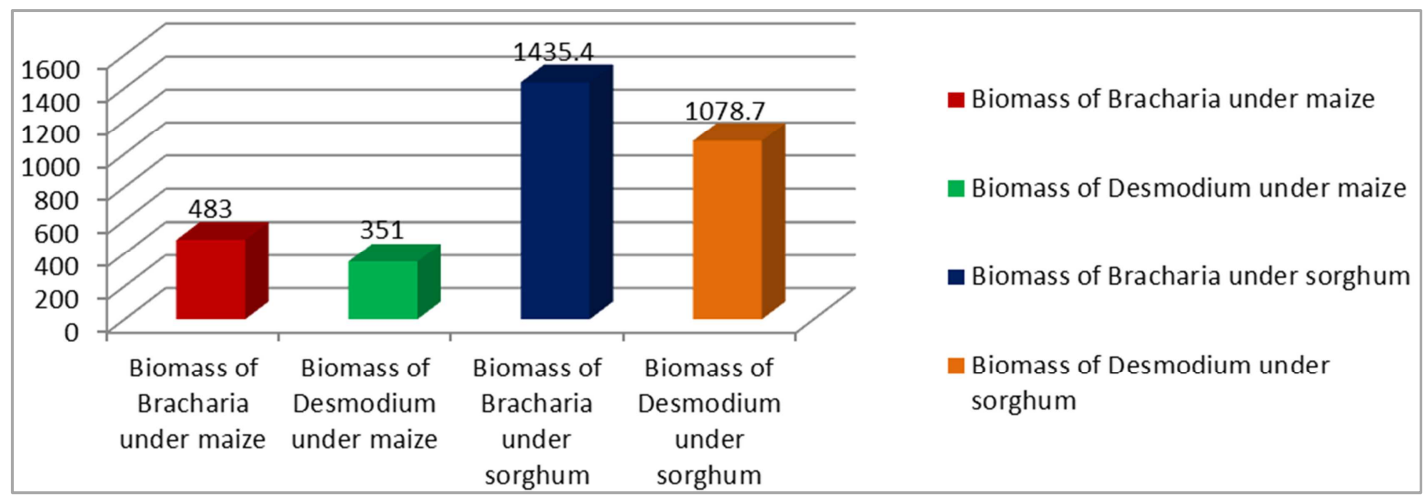

Figure 1. Average Biomass of Desmodium and Bracharia harvested in $\mathrm{Kg} / \mathrm{ha}$.

As indicted on Graph 1, the average Biomass of Bracharia and Desmodium under Maize production is $483 \mathrm{~kg}$ and 351 $\mathrm{kg}$ per hectare respectively. The average Biomass of Bracharia and Desmodium under sorghum production is $1435 \mathrm{~kg}$ and $1078.7 \mathrm{~kg}$ per hectare respectively. The average Biomass of Bracharia is higher than that of Desmodium both under sorghum and maize production. On the other hand the average biomass of both Bracharia and Desmodium is higher under sorghum production than under maize production. In general, the biomass of Bracharia produced is the solution for the animal feed constraint in the area besides controlling the stem borer infestation and reducing soil erosion. This is in conformity with [14] whose finding shows the effectiveness of push-pull technology in providing high-value animal fodder which it urn contribute to the improvement in milk and meat production. Furthermore, the technology (Desmodium) is efficient in enhancing soil fertility, maintaining soil moisture and preventing soil degradation.

\subsection{Farmers' Perception on Push-pull Technology}

Most of the sample farm households are give their own perception on push pull technology regarding its importance for livestock forage, controlling the striga and stem borer infestation, increasing soil fertility, reducing soil erosion, maintaining soil moisture content and others. Some of the sample farm households who did not apply the technology for maize and sorghum production properly, can't judge and understand the importance of the technology well.

Most of the farmers are fully agree, others agree and the rest of them were fully disagree and disagree with the ideas regarding to the importance of the push-pull technology.

From the total sample farm households, about $77.8 \%$ of them were fully agree and $9 \%$ of them were agree with the idea that push-pull technology is efficient in controlling stem borer. But, the rest $8.6 \%$ of them were can't judge anything regarding the importance of the technology in controlling stem borer. Only $1.2 \%$ of farmer was disagreeing and fully disagreeing with the idea. $71.6 \%$ of the sample farm households were fully agree and $18.5 \%$ were agree with the idea that push-pull technology is efficient in controlling stem striga.

Only $4.9 \%$ of them were unable to judge anything regarding the importance of the technology in controlling striga and only few farmers were disagree with the idea. $87.7 \%$ of the sample farm households were fully agrees and $9.9 \%$ were agreeing with the idea that push-pull technology is very important for livestock forage.

On the other hand, $65.4 \%$ of the sample farmers were fully agree and $12.4 \%$ were agree with the idea that push-pull technology is important for increasing milk yield since it is used as an important animal feed. However, $22.2 \%$ of them were unable to judge whether the push-pull technology is useful to increase milk yield or not. No farmers were fully disagreeing or disagree with this idea.

Most of the sample farm households understand as pushpull technology is very important for animal fattening since it is good animal forage. $76.5 \%$ were fully agreed and $13.6 \%$ were agreed with this idea. However $9.9 \%$ of them were unable to judge about the importance of the technology for enhancing animal fattening. No farmers were fully disagreed or disagreed with this idea. In addition to this they also forward their own perception regarding to the efficiency of the technology in improving soil fertility and maintaining soil moisture content. $70.4 \%$ and $83.9 \%$ of the sample farm households were fully agreed with the idea that the push pull technology is efficient in improving soil fertility and maintaining soil moisture content respectively. The farmers also raised the efficiency of push-pull technology in reducing soil erosion. Most of them (77.8\%) were fully agreed and about $19.7 \%$ of them were agreed with this idea. However, no one is fully disagreed or disagree with this idea. This implies that all of the farmers were accept the technology regarding to its efficiency of reducing soil erosion. The perception of the farmers on push-pull-technology is discussed below on the figure 2 .

As indicated on figure 2, most of the farmers were fully agree with the ideas regarding the importance and efficiency of push-pull technology in controlling stem borer, striga, increasing availability of livestock forage, enhancing milk yield, animal fattening, improving soil fertility, maintaining soil moisture content and reducing soil erosion. This implies that most of the farmers were making push pull technology their own choice to get all of the above benefit packages at the same time. However, few farmers were unable to judge the importance of the technology. They were not implemented the technology properly and their management 
practices were so poor. As a result they were unable to observe the advantages of the technology as those farmers implemented the technology properly with a good management practices. In general push-pull technology is providing farmers with a lot of benefits packages at the same time and thereby increasing their crop yield.

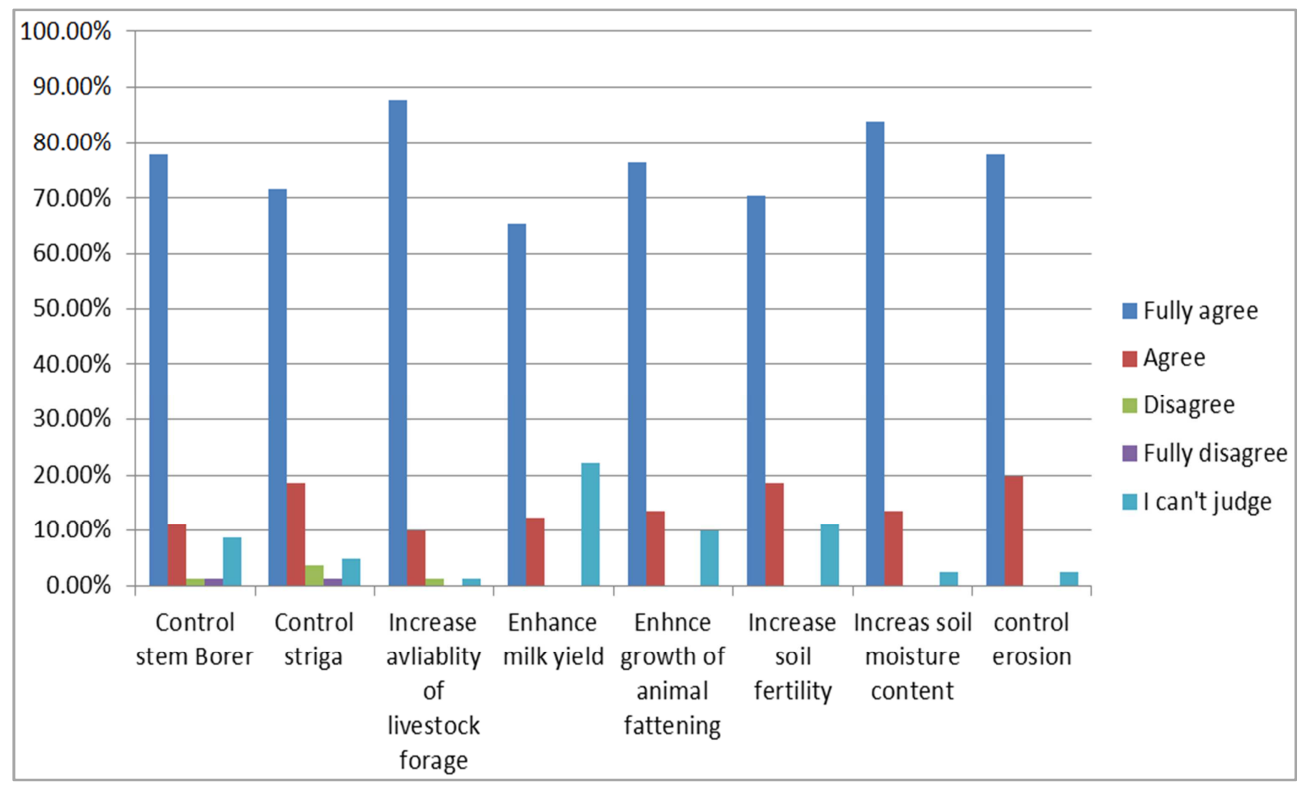

Figure 2. Perception of farmers on push-pull technology.

As empirical results in section 3.4 shows, Farmers got better yield under push-pull technology application than under sole cropping. The farmers perception on importance of push-pull technology in increasing yield is also proof this. The perception of farmers on push technology regarding its importance in increasing yield is discussed below.

Table 3. Perception of farmers on push technology regarding its importance in increasing yield of maize and sorghum.

\begin{tabular}{|c|c|c|c|c|}
\hline Farmers perception & $\mathbf{N}$ & Degree of perception & Frequency & Percent \\
\hline \multirow{3}{*}{$\begin{array}{l}\text { Push-pull technology is important to } \\
\text { increase maize yield }\end{array}$} & \multirow{3}{*}{8} & Fully agree & 7 & 87.5 \\
\hline & & Agree & 1 & 12.5 \\
\hline & & Total & 8 & 100 \\
\hline \multirow{5}{*}{$\begin{array}{l}\text { Push-pull technology is important to } \\
\text { increase maize yield }\end{array}$} & \multirow{5}{*}{77} & Fully Agree & 62 & 80.5 \\
\hline & & Agree & 9 & 11.7 \\
\hline & & I can't judge & 3 & 3.9 \\
\hline & & Disagree & 2 & 2.6 \\
\hline & & Total & 77 & 100 \\
\hline
\end{tabular}

As indicated in table 3, farmers applying push-pull technology for maize and sorghum production are interviewed independently regarding its importance for increasing maize and sorghum yield. From the total sample farm households, 8 farmers were implement push-pull technology for maize production. These farmers were interviewed about the push-pull technology independently regarding its importance for increasing maize yield. From these, most of them (7) were fully agreed and the remaining 1 farmer was agreed with the idea. On the other way all of them are understand about the efficiency of the technology to increase maize yield by reducing striga and stem borer infestation and also providing other benefits packages like improving soil fertility and reducing soil erosion at the same time.

From total sample farm house holds 77 of them were used the push-pull technology for sorghum production. These farmers were also interviewed independently as that of maize about the push-pull technology regarding its importance for increasing sorghum yield. From these, most of them $(80.5 \%)$ were fully agree and $11.9 \%$ of them were agree with the idea that push-pull technology is important for increasing sorghum yield.

However, $3.9 \%$ of them were unable judge whether the technology is increasing sorghum yield or not. They were not implementing the technology properly and as a result the efficiency of the technology is not as expected and they also unable to observe its importance and significant effect on yield.

Only few farmers were given a negative perception. 2 farmers were disagreed and the other 1 farmer was fully disagreed with the idea. To sum up, most of the sample farm households applying push-pull-technology for sorghum production are understand about the efficiency of the technology to increase sorghum yield and its importance to provide other necessary benefits packages at the same time which are contributing for yield increment. This result is supported by the finding of Ogot [16] which stated that 
maize yield under push-pull technology is more than three times the yield under conventional maize plots, that is $1393 \mathrm{~kg} / \mathrm{ha}$ under push-pull and $401 \mathrm{~kg} / \mathrm{ha}$ under Non pushpull maize plots.

\subsubsection{Perception of Farmers on Importance and Limitation of Desmodium}

Farmers were raised different benefits (advantage) and limitations of Desmodium in order of importance. Most of the respondents were raise many advantages of Desmodium such as improving soil fertility, reduce soil erosion, for livestock forage, reduce striga and stem borer infestation. The respondents were put these advantages of Desmodium order of importance. From total sample farm households, about $91.3 \%$ of them were responding as Desmodium is important for live stock forage. From these, most of them $(50.6 \%)$ were rank this advantage of the technology (Desmodium) on the 1 st rank. The rest $24.7 \%$ and $14.8 \%$ of them were put this importance (advantages) of the technology on the ${ }^{2 \text { nd }}$ and $3^{\text {rd }}$ rank respectively. Only $1.2 \%$ of them were put the advantage of Desmodium for livestock forage on the $4^{\text {th }}$ rank.

About $49.6 \%$ of the respondents respond that as Desmodium is important for reducing soil erosion. From these, $22.2 \%$ and $17.3 \%$ were put this advantage of the technology (Desmodium) on the $2^{\text {nd }}$ and $3^{\text {rd }}$ rank respectively.

The rest $6.2 \%$ and $1.2 \%$ of them were put this importance (advantages) of the technology on the $1^{\text {st }}$ and $4^{\text {th }}$ rank respectively. On the other hand $55.6 \%$ of the respondents were raised the importance of Desmodium in reducing striga infestation. From these, $(22.2 \%)$ were rank this advantage of the technology (Desmodium) on the $2^{\text {nd }}$ rank. The rest $17.3 \%$ and $12.4 \%$ of them were put this importance (advantages) of the technology on the $1^{\text {st }}$ and $3^{\text {rd }}$ rank respectively. Only $3.7 \%$ of them were put the advantage of the technology (Desmodium) regarding to its ability to reduce striga infestation on the $4^{\text {th }}$ rank (table 4 ).

Table 4. Benefits of Desmodium in order of importance.

\begin{tabular}{lllll}
\hline Benefits & $\mathbf{1}^{\text {st }}(\mathbf{\%})$ & $\mathbf{2}^{\text {nd }}(\mathbf{\%})$ & $\mathbf{3}^{\text {rd }}(\mathbf{\%})$ & $\mathbf{4}^{\text {th }}(\mathbf{\%})$ \\
Improving soil fertility & 6.2 & 3.7 & 16 & 7.4 \\
Reduce soil erosion & 6.2 & 22.2 & 17.3 & 1.2 \\
For livestock forage (animal feed) & 50.6 & 24.7 & 14.8 & 1.2 \\
Reduce striga infestation & 17.3 & 22.2 & 12.4 & 3.3 \\
Maintaining soil moisture & 2.5 & 12.4 & 11.1 & 3.7 \\
Reduce stem borer infestation & 4.9 & 9.9 & 4.9 & 3.7 \\
Improve milk production & 6.2 & 2.5 & 3.7 & 0 \\
\hline
\end{tabular}

As indicated on table 4, majority (50.6\% and $24.7 \%$ ) of the sample farm households were indicating the advantage of Desmodium for livestock forage on the $1^{\text {st }}$ and $2^{\text {nd }}$ rank respectively. The importance of Desmodium in reducing soil erosion and striga infestation is also raised by the majority $(22.2 \%)$ of the sample farm households on the $2^{\text {nd }}$ rank. On the $3^{\text {rd }}$ rank the advantages of Desmodium reducing soil erosion and improving soil fertility were raised by majority $(17.3 \%$ and $16 \%)$ of the sample farm households respectively when compared with other advantages of the technology. Live stock forage is the most important benefits of the technology in which most of the farmers were put on the $1^{\text {st }}$ and $2^{\text {nd }}$ rank. The advantage of the technology (Desmodium) for reducing soil erosion and striga infestation are also pertinent benefits of the technology which were given $2^{\text {nd }}$ rank by most of the respondents when compared with other advantages of Desmodium.

The benefit of the technology (Desmodium) in improving soil fertility was also given $3^{\text {rd }}$ rank by most of the respondents next to its benefits for reducing soil erosion. Generally, this result implies that farmers aware more and had a good understanding on the advantages of Desmodium regarding to its importance for livestock forage, reducing soil erosion, minimizing striga infestation and improving soil fertility.

Although Desmodium provides a lot of benefits packages for the farmers, some of the respondents were raised certain limitations of the technology like its susceptibility to drought, its low efficiency to control stem borer and its bad root system that makes the soil harder to plough. Most of the sample farm households were told that as Desmodium has no limitation in their crop production process.

From total sample farm house holds, only $3.7 \%$ of them were raised about the limitation of Desmodium regarding to its low tolerance to drought problem and only $1.2 \%$ of the respondent were raised the problem on the efficiency of

Desmodium to control stem borer. The other $1.2 \%$ were raised a problem on root system of Desmodium as its limitation which makes soil harder to plough.

\subsubsection{Perception of Farmers on Importance and Limitation of Bracharia}

Farmers were raised different benefits (advantage) and limitations of Bracharia in order of importance. Most of the respondents were raise many advantages of Bracharia such as improving soil fertility, reduce soil erosion, for livestock forage, reduce striga and stem borer infestation. The respondents were put these advantages of Bracharia in order of importance. From total sample farm households, about $86.5 \%$ of them were responding as Bracharia is important for live stock forage. From these, most of them (59.3\%) were rank this advantage of the technology (Bracharia) on the 1st rank. The rest $17.3 \%$ and $9.9 \%$ of them were put this importance (advantages) of the technology on the ${ }^{\text {2nd }}$ and $3^{\text {rd }}$ rank respectively. No one was put the advantage of Bracharia for livestock forage on the $4^{\text {th }}$ rank.

About $82.5 \%$ of the respondents respond that as Brachiaria is important for reducing soil erosion. From these, (33.3\%) 
were rank this advantage of the technology (Bracharia) on the $2^{\text {nd }}$ and $3^{\text {rd }}$ rank. The rest $14.8 \%$ and $1.2 \%$ of them were put this importance (advantages) of the technology on the $1^{\text {st }}$ and $4^{\text {th }}$ rank respectively. On the other hand $67.9 \%$ of the respondents were raised the importance of Brachiaria in reducing stem borer infestation. From these, (33.3\%) were rank this advantage of the technology (Bracharia) on the $2^{\text {nd }}$ rank. The rest $16.1 \%$ and $14.8 \%$ of them were put this importance (advantages) of the technology on the $1^{\text {st }}$ and $3^{\text {rd }}$ rank respectively. Only $3.7 \%$ of them were put the advantage of the technology (Bracharia) regarding to its ability to reduce stem borer infestation on the $4^{\text {th }}$ rank (table 5).

Table 5. Benefits of Bracharia in order of importance.

\begin{tabular}{|c|c|c|c|c|c|}
\hline Benefits & $1^{\text {st }}$ (in \%) & $2^{\text {nd }}(\%)$ & $3^{\text {rd }}(\%)$ & $4^{\text {th }}(\%)$ & Total \\
\hline Improving soil fertility & 3.7 & 2.5 & 6.2 & 1.2 & 13.6 \\
\hline Reduce soil erosion & 14.8 & 33.3 & 33.3 & 1.2 & 82.6 \\
\hline For livestock forage (animal feed) & 59.3 & 17.3 & 9.9 & 0 & 86.5 \\
\hline Reduce striga infestation & 3.7 & 3.7 & 6.2 & 0 & 13.6 \\
\hline Maintaining soil moisture & 1.2 & 2.5 & 2.5 & 2.5 & 8.7 \\
\hline Reduce stem borer infestation & 16.1 & 33.3 & 14.8 & 3.7 & 67.9 \\
\hline Improve milk production & 1.2 & 0 & 0 & 1.2 & 2.4 \\
\hline
\end{tabular}

As indicated on table 6, majority (59.3\%) of the sample farm household were indicating the advantage of Bracharia for livestock forage on the $1^{\text {st }}$ rank. The importance of Bracharia in reducing soil erosion and stem bore infestation is raised by majority (33.3\%) of the sample farm households on $2^{\text {nd }}$ rank. On the $3^{\text {rd }}$ rank the advantages of Bracharia in reducing soil erosion and stem borer infestation were raised by majority $(33.3 \%$ and $14.8 \%)$ of the sample farm households respectively when compared with other advantages of the technology. Live stock forage is the most important benefits of the technology in which most of the farmers were put on the $1^{\text {st }}$ rank.

The advantage of the technology (Bracharia) for reducing soil erosion and stem borer infestation are also pertinent benefits of the technology which were given $2^{\text {nd }}$ and $3^{\text {rd }}$ rank by most of the respondents when compared with other advantages of Bracharia. Generally this implies that Farmers aware more and had a good understanding on the advantages of Bracharia regarding to its importance for livestock forage, reducing soil erosion and stem borer infestation. This is in line with [17] who reported that majority of the smallholder farmers practicing push-pull technology in their maize farm gave high ratings regarding the advantage of the technology in improving the access to animal feed or forage, reduces soil erosion and control stem borer damage.

On the other hand, some of the respondents were raised certain limitations of the technology (Bracharia) like its susceptibility to drought, its low inefficiency to control striga and its bad root system that makes the soil dry harder to plough, Even though it provides a lot of benefits packages for the farmers. Most of the sample farm households were told that as Bracharia has no limitation in their crop production process.

From total sample farm house holds, only $2.5 \%$ of them were raised about the limitation of Bracharia regarding to its low tolerance to drought problem. The other $2.5 \%$ of the respondents was told that Bracharia is not important to control striga. About $1.2 \%$ of them were told that as Bracharia has limitation regarding to high nutrient $t$ competition with the crop. $2.5 \%$ of the respondents were raised a problem on root system of Bracharia as its limitation which makes soil more dry and harder to plough. Generally, most of the sample farm households were not raised any limitation of Bracharia. Only $8.7 \%$ of them were raised some limitations of Bracharia they had faced on their field.

\subsection{The Role of Farmer-farmer Information Flow}

Most of the farmers were passed the information about the importance of push-pull technology for maize and sorghum production for other farmers who have no information and access to implement the technology. The farmers were implementing the technology by organizing as a group of FRGs (Farmers Research Groups). The sample farmers who use push-pull for sorghum and maize production are interviewed independently about the information they passed for Non FRG Individual farmers without access and information about the technology. From a total of 77 sample FRG farm household applying push-pull for sorghum production, about $94.8 \%$ of them were passed the information about the importance of push-pull technology in sorghum production for Non-FRG individual farmers who have no information about it. Minimum of 1 and maximum of 150 Non -FRG individual farmers were got information on push pull application for sorghum production and its importance. 12 Non -FRG individual farmers were got information on average from each of these Sample FRG farmers who were passing the information about the use of technology for sorghum production.

From a total of 8 sample FRG farm household applying push-pull for maize production, all $(100 \%)$ of them were passed the information about the importance of push-pull technology in Maize production for other Non-FRG individual farmers who have no access and information about it. Minimum of 2 and maximum of 10 Non FRG individual farmers were got information on push pull application for maize production and its importance. Each of sample FRG farmers using push pull technology for maize production are passing the information about the importance of implementing the technology for maize production for about 4 farmers on average.

The number of FRG sample farmers passing information and the average number of Non-FRG individual farmers 
getting information about the push-pull technology is discussed below on figure 3 .

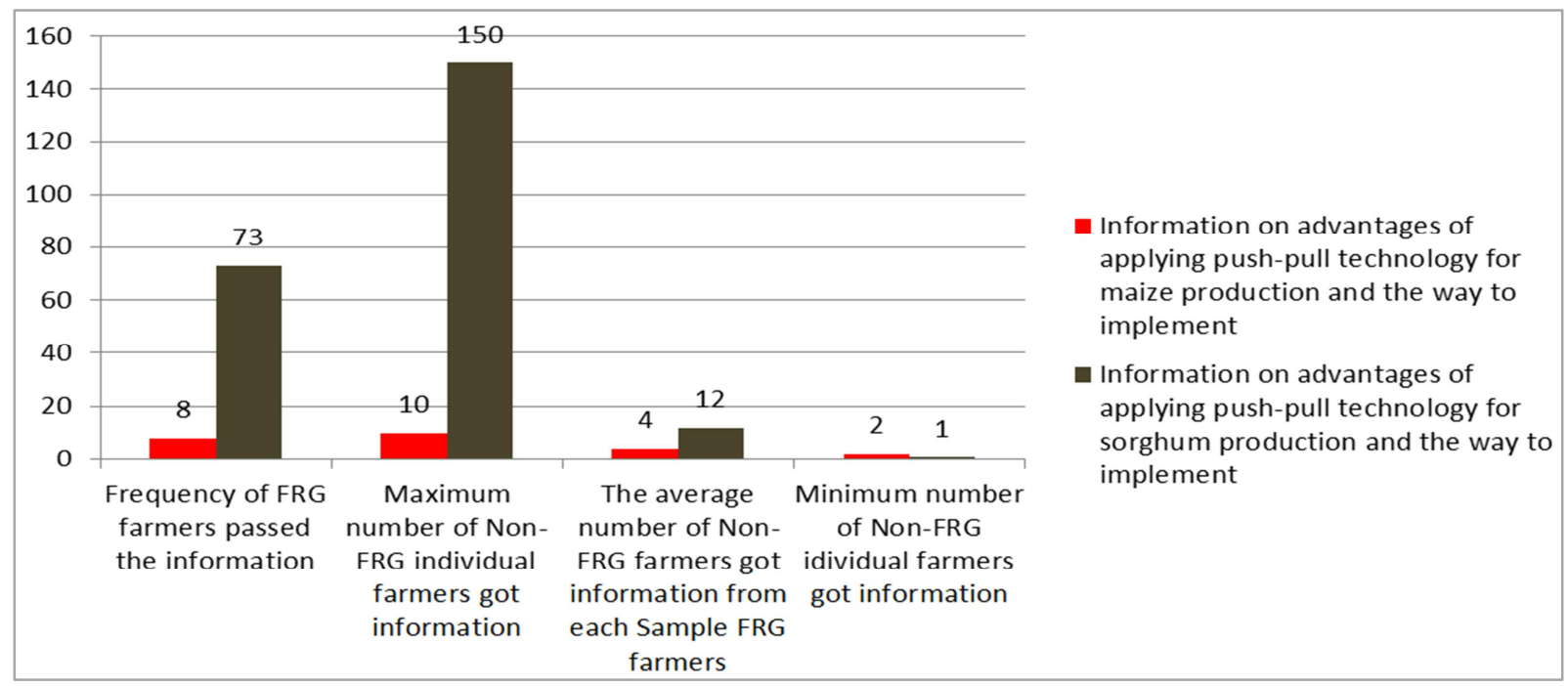

Figure 3. Information flow on importance of push-pull technology for maize and sorghum production.

According to the result indicated on figure 3 , all of the respondents employing the push-pull technology for sorghum were passed the information about the technology for the maximum of 150 and minimum of 1 other non-FRG farmers who had not information about it.

On average 12 Non-FRG farmers obtained information about the push-pull technology implementation for sorghum from the respondents (FRG farmers) who had implemented the technology for sorghum. On the other hand, those farmers who implement the push-pull technology for maize were passed the information on how to implement the technology with maize and its advantage in striga and steam borer control. All of the farmers who were implement the push-pull technology for maize were passed the information about the implementation of the technology for maize and its advantage in striga and stem borer control for those farmers who had no information about it.

Minimum of 2 and maximum of 10 Non-FRG farmers had got information about the implementation of push-pull technology for maize and its importance from each farmer implementing the technology for maize. Each FRG farmers implementing push-pull for maize were passed the information about the application of the push -pull technology for maize production and its importance for 4 non FRG farmers on average.

From the above discussion we understand that, farmer to farmer information flow is the main pathway for the adoption of push-pull technology in the study area. This coincide with [8] whose report shows the farmer-to-farmer approaches plays a significant role in the dissemination of push-pull technology through an exchange of information about the technology among them.

\subsection{Farmers' Opinion on Push-pull Technology}

As the result of this study shows, from total sample farm households, some $(42 \%)$ of the sample farm households were raised their comment on provision of training for farmers and DAs for a successful implementation of the technology, provision of the technology (Desmodium and Bracharia seed) on time, availability of improved sorghum to be implemented with the push-pull technology, spacing to be used between the intercrop plant and Desmodium and monitoring and evaluation of the technology. From these about, $13.6 \%$ of the respondents were commented that improved sorghum varieties should be provided and implemented together with push-pull technology. $18.5 \%$ of them were commented on delivery (provision) of inputs (Desmodium and Bracharia seed) on time. $4.9 \%$ of the respondent was commented that as the provision of training for farmers and DAs on push-pull is necessary for a successful implementation of the technology. The other $2.5 \%$ of them were raised their comment on the idea that further study on spacing to be used between the intercrop plant and Desmodium is necessary. The rest $2.5 \%$ were comment that as monitoring and evaluation of the technology is expected from Melkassa Agricultural Research center.

\section{Summary and Implications}

The study concludes that the number of farmers using the push-pull technology is increasing from 2012 to 2014, even though some of them were forced to stop using the technology due to extreme drought rain shortage) in 2014 growing season. This is due to the reason that, Non FRG individual farmers were got good information about the technology from the previously established FRG members and started to involve in implementation of the technology for sorghum by establishing a new FRG with a good understanding and information about the technology. On the other hand this implies that, farmer to farmer information flow is the main pathway for the adoption of push-pull technology in the study area.

Farmers had a good understanding regarding the advantages of push-pull technology for reducing stem borer, 
striga infestation, soil erosion, improving livestock forage availability and soil fertility. Farmers got better yield under push-pull technology application than under sole cropping. This implies that push-Pull technology is important for improving yield by providing different benefit packages like improving soil fertility, reducing soil erosion, reducing the risk on yield due to stem borer and striga.

Most of the farmers were fully agree with the ideas regarding to the importance and efficiency of push -pull technology in controlling stem borer, striga, increasing availability of livestock forage, enhancing milk yield, animal fattening, improving soil fertility, maintaining soil moisture content and reducing soil erosion. This implies that most of the farmers were making push pull technology their own choice to get all of the above benefit packages at the same time. In general push-pull technology is providing farmers with a lot of benefits packages at the same time and thereby increasing their crop yield.

Although Desmodium provides a lot of benefits packages for the farmers, some of the respondents were raised certain limitations of the technology like its susceptibility to drought and its bad root system that makes the soil harder to plough.

They were also comment that, as there is poor facilities regarding provision of training about the technology for Farmers and DAs, untimely availability (provision) of Desmodium and Bracharia seed, lack of improved sorghum varieties to be planted with the technology and lack of appropriate and recommended spacing to be used between the intercrop plant and Desmodium. Therefore, given the advantages of the technology, concerned bodies and organizations should work further to improve the availability of the technology and to improve the agricultural production and productivity.

\section{References}

[1] Calatayud, P. A., Le Ru, B. P., Van den Berg, J., Schulthess, F. (2014). Ecology of African maize stalk borer. Busseola fusca (Lepidoptera: Noctuidae) with special reference to insect-plant interactions. Insects 2014, 5, 539-563.

[2] Cook, S. M., Khan, Z. R., \& Picket, J. A. (2007). The use of push-pull strategies in integrated pest management. Annu. Rev. Entomol 52: 375-400.

[3] Food and Agricultural Organization. (2006). Food Security and Agricultural development in Sub-Saharan Africa. Building a case for more public support, working paper no. 01/E. Rome, Italy.

[4] Gebisa E. (2007). Integrating new technologies for striga control-Towards ending the withch-Hunt. World Scientifiic publishing Co. Pte. Ltd. Avaliable: http://www.worldscibooks.com/lifesci/640.htm

[5] Getu, E., Overholt, W. A., Kairu, E. (2002). Status of stemborers and their managemnt in Ethiopia. In proceedings of the Integrated Pest Management Conference, Kampla, Uganda, 812, september 2002.

[6] Hassanali, A., Harren, H., Khan, Z. R., Picket, J. A., \& Wood lock, Ch. M. (2008). Integrated pest Management: the pushpull approach for controlling insect pests and weeds of cereals, and its potential for other agricultural systems including animal husbandry. Phil. Trans. R. Soc. B 363 (491): 611-621.

[7] Kassie, M., Stage, J., Diiro, G., Muriithi, B., Murich, G., Ledermann, S. T., Pittchar, J., Midega, C., Khan, Z. (20180. Push-Pull farming systems in kenya: Implications for economic and social welfare. Land Use Policy, no. 77. Pp 186-198.

[8] Khan, Z., Midega, C., Pitcharr, J., Pickett, J. and Bruce, T. (2011). Push-Pull technology: A conservation agriculture approach for integrated management of insect pests, weeds and soil health in Africa. International Journal of Agricultural Sustainablity. Vol. 9 (1), Pp 162-170.

[9] Khan, Z. R., \& Pickett, J. A. (2004). The 'Push-pull' Strategy for Stemborer Management: A Case Study in Exploiting Biodiversity and Chemical Ecology. In: Gurr, G. M., Wratten, S. D., Altieri, M. A., (Eds.), Ecological Engineering for Pest Management: Advances in Habitat Manipulation for Arthropods. CABI Publishing, CABI, Wallingford, Oxon, U.K.

[10] Khan, Z. R., Hassanali, A., Overholt, W., Khamis, T. M., Hooper, A. M., Pickett, A. J., Wadhams, L. J., \&Woodlock, C. M. (2002). Control of witchweed Striga hermothica by intercropping with Desmodium spp., and the mechanism defined as allelopathic. Journal of Chemical Ecology, 28, 1871-1885.

[11] Khan, Z. R., Midega, C. A. O., Wadhams, L. J., Pickett, J. A.,\& Mumuni, A. (2007). Evaluation of Napier grass (Pennisetumapurpureum) varieties for use as trap plants for management of African stemborer (Busseolafusca) in a 'Pushpull' strategy. Entomological Experimental Application, 124, 201-211.

[12] Khan, Z. R., Midega, C. A. O., Amudavi, D. M., Hasanali, A., \& Pickett, J. A. (2008). On farm evaluation of push-pull technology for the control of stem borer and striga weed on maize in western kenya. Field Crops Reserarch 106 (3): 224223.

[13] Midega, C. A., Wasonga, C. J., Hooper, A. M., Pickett, J. A., Khan, Z. R. (2017). Drought-Tolerant Desmodium Species Effectively suppresses Parasitic Striga Weed and Improve Cereal Grain Yields in Western Kenya. Crop Prot. 2017, 98, 94-101.

[14] Midega, C. A. O., Pittcharr, J. O., Pickett, J. A., Hailu, G. W., Khan, Z. R. (2018). A climate-adapted push-pull effectively controls fall armyworm, Spodotera frugiperda (J E Smith), in maize in East Africa. Crop Prot. 2018, 105, 10-15.

[15] Oben, E. O., Ntonifor, N. N., Kekeunou, S., Abbeytakor, M. (2015). Farmers Knowledge and perception on maize stem borers and their indigenous control methods in south western region of cameroon. Journal of Ethnobio. Ethnomed. 2015, 11, 177.

[16] Ogot, N. O., Pitcharr, J. O., Midega, C. A. O. and Khan, Z. R. (2018). Attributes of push-pull technology in enhancing food and nutrition security. African Journal of agriculture and Fod Security. Vol. 6 (3), Pp. 229-242, March, 2018.

[17] Teshome, K., Esayas, M., Bayu, E., Menale, K. and Tadele, T. (2019). Effect of the push-pull cropping system on maize yield, Stem-borer infestation and farmers' perception. Journal of Agronomy, 2019, 9, 452. Avaliable: www.mpdi.com/journal/agronomy 